\title{
Caddo Vessels from the W. O. Ziegler Farm (41WD30) and Claude Burkett (41WD30) Sites in the Upper Sabine River Basin in Wood County, Texas
}

Timothy K. Perttula

Heritage Research Center, Stephen F. Austin State University

Follow this and additional works at: https://scholarworks.sfasu.edu/ita

Part of the American Material Culture Commons, Archaeological Anthropology Commons, Environmental Studies Commons, Other American Studies Commons, Other Arts and Humanities Commons, Other History of Art, Architecture, and Archaeology Commons, and the United States History Commons

Tell us how this article helped you.

This Article is brought to you for free and open access by the Center for Regional Heritage Research at SFA ScholarWorks. It has been accepted for inclusion in Index of Texas Archaeology: Open Access Gray Literature from the Lone Star State by an authorized editor of SFA ScholarWorks. For more information, please contact cdsscholarworks@sfasu.edu. 


\section{Caddo Vessels from the W. O. Ziegler Farm (41WD30) and Claude Burkett (41WD30) Sites in the Upper Sabine River Basin in Wood County, Texas}

\section{Creative Commons License}

\section{(c) (1) (8)}

This work is licensed under a Creative Commons Attribution-NonCommercial 4.0 International License 


\title{
Caddo Vessels from the W. O. Ziegler Farm (41WD30) and Claude Burkett (41 WD30) Sites in the Upper Sabine River Basin in Wood County, Texas
}

\author{
Timothy K. Perttula
}

\section{INTRODUCTION}

Caddo ceramic vessels were collected at the W. O. Ziegler Farm (41WD30) and Claude Burkett (41WD31) sites in 1930 during archaeological investigations in Wood County by The University of Texas (Wilson and Jackson 1930). The one vessel from the W. O. Ziegler Farm site, located in the Lake Fork Creek drainage in the upper Sabine River basin (Figure 1), was found in 1918 at a depth of ca. $1.2 \mathrm{~m}$ by the landowner while digging a storm cellar. University of Texas archaeologists purchased the vessel in August 1930.

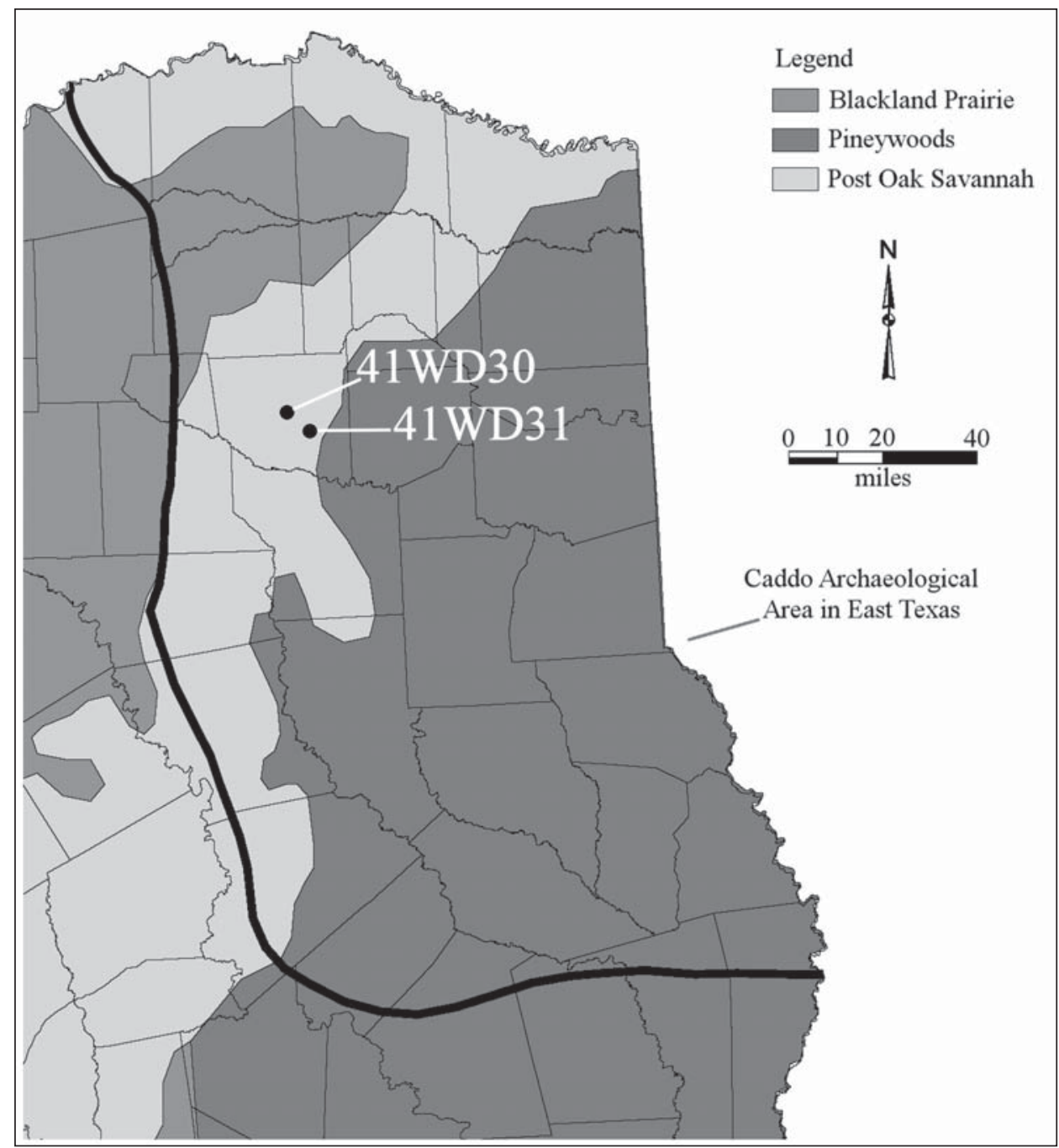

Figure 1. Locations of the W. O. Ziegler Farm (41WD30) and Claude Burkett (41WD31) sites in East Texas. 
The Claude Burkett site is in the Big Sandy Creek basin in the upper Sabine River basin (see Figure 1). The landowner found two ceramic vessels after a heavy rain had eroded them from the site. University of Texas archaeologists also purchased these vessels in August 1930. Wilson and Jackson (1930) excavated a few test trenches at the site at that time, but did not recover any more vessels. They did note that ceramic sherds were present in small amounts between ca. $15-30 \mathrm{~cm}$ bs in the test trenches.

\section{W. O. Ziegler Farm (41WD30) Vessel}

SITE NAME OR SITE NUMBER: W. O. Ziegler Farm

VESSEL NO.: 1

VESSEL FORM: Bottle

NON-PLASTICS AND PASTE: grog

RIM AND LIP FORM: N/A

CORE COLOR: $\mathrm{G}$ (fired in a reducing environment and cooled in the open air)

INTERIOR SURFACE COLOR: dark grayish-brown

EXTERIOR SURFACE

COLOR: dark yellowish-brown

WALL THICKNESS (IN MM): neck, $8.8 \mathrm{~mm}$

INTERIOR SURFACE TREATMENT: none

EXTERIOR SURFACE TREATMENT: burnished

HEIGHT (IN CM): 14.0+

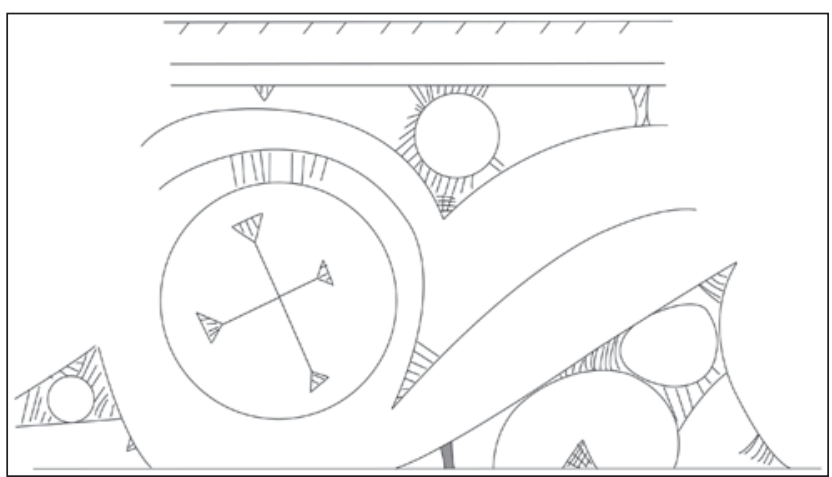

ORIFICE DIAMETER (IN CM): N/A

Figure 2. Ripley Engraved bottle from the W. O. Ziegler Farm (41WD30).

DIAMETER AT BOTTOM OF RIM OR NECK (IN CM): 4.4; maximum body diameter is $15.0 \mathrm{~cm}$

BASE DIAMETER (IN CM) AND SHAPE OF BASE: 7.6; circular and flat

ESTIMATED VOLUME (IN LITERS): 0.4+

DECORATION (INCLUDING MOTIF AND ELEMENTS WHEN APPARENT): The top of the vessel is decorated with three horizontal engraved lines, the bottom line of which has diagonal spur marks. The main decorative motif on the vessel body is a scroll and circle repeated three times around the vessel. The circle of the motif has an equal-arm cross with hatched triangle elements on the ends of the arms (Figure 2). The upper triangular-shaped scroll fill zone has three engraved circles surrounded by hatched or cross-hatched zones. The lower triangular-shaped scroll fill zone has circle and oval elements embedded in the zone, and surrounded by hatched areas. The large oval has a single small cross-hatched pendant triangle element.

PIGMENT USE AND LOCATION ON VESSEL: red clay pigment in the engraved lines

TYPE AND VARIETY (IF KNOWN): Ripley Engraved 


\section{Claude Burkett (41WD31) Vessels}

SITE NAME OR SITE NUMBER: Claude Burkett

VESSEL NO.: 1

VESSEL FORM: Carinated bowl

NON-PLASTICS AND PASTE: grog

RIM AND LIP FORM: Direct rim and rounded lip

CORE COLOR: $\mathrm{F}$ (fired in a reducing environment and cooled in the open air)

INTERIOR SURFACE COLOR: light brown; fire clouds on the body and base

EXTERIOR SURFACE COLOR: light brown; fire clouds on the body and base

WALL THICKNESS (IN MM): rim, $3.3 \mathrm{~mm}$

INTERIOR SURFACE TREATMENT: smoothed

EXTERIOR SURFACE TREATMENT: smoothed

HEIGHT (IN CM): 7.6

ORIFICE DIAMETER (IN CM): 11.4

DIAMETER AT BOTTOM OF RIM OR NECK (IN CM): 11.5

BASE DIAMETER (IN CM) AND SHAPE OF BASE: 7.0; circular and flat

ESTIMATED VOLUME (IN LITERS): 0.5

DECORATION (INCLUDING MOTIF AND ELEMENTS WHEN APPARENT): The rim of the vessel is decorated with 20 engraved pendant triangles filled with cross-hatched engraved lines (Figure 3).

PIGMENT USE AND LOCATION ON VESSEL: none

TYPE AND VARIETY (IF KNOWN): Sanders Engraved

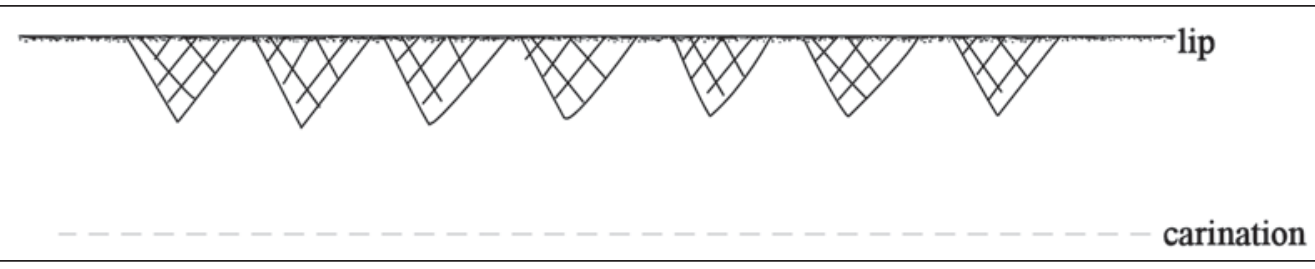

Figure 3. Sanders Engraved carinated bowl from the Claude Burkett site (41WD31). 
SITE NAME OR SITE NUMBER: Claude Burkett

VESSEL NO.: 2

VESSEL FORM: Jar

NON-PLASTICS AND PASTE: grog

RIM AND LIP FORM: Everted rim and rounded lip

CORE COLOR: F (fired in a reducing environment and cooled in the open air)

INTERIOR SURFACE COLOR: brown

EXTERIOR SURFACE COLOR: brown; fire clouds on the rim and body

WALL THICKNESS (IN MM): rim, $5.2 \mathrm{~mm}$

INTERIOR SURFACE TREATMENT: smoothed

EXTERIOR SURFACE TREATMENT: smoothed

HEIGHT (IN CM): 8.9

ORIFICE DIAMETER (IN CM): 15.0

DIAMETER AT BOTTOM OF RIM OR NECK (IN CM): 14.2

BASE DIAMETER (IN CM) AND SHAPE OF BASE: 12.7; circular and rounded

ESTIMATED VOLUME (IN LITERS): 0.8

DECORATION (INCLUDING MOTIF AND ELEMENTS WHEN APPARENT): The rim of the vessel is decorated with at least 11 semi-circular engraved elements with small hatched or excised ovals pendant from the semi-circles (Figure 4). The vessel body has sets of five semi-circular zones filled with cross-hatched engraved lines, as well as five sets of semi-circular engraved lines with hatched or cross-hatched ovals pendant from the outer semi-circular line. The vessel is also lip notched.

PIGMENT USE AND LOCATION ON VESSEL: none

TYPE AND VARIETY (IF KNOWN): Unidentified fine ware

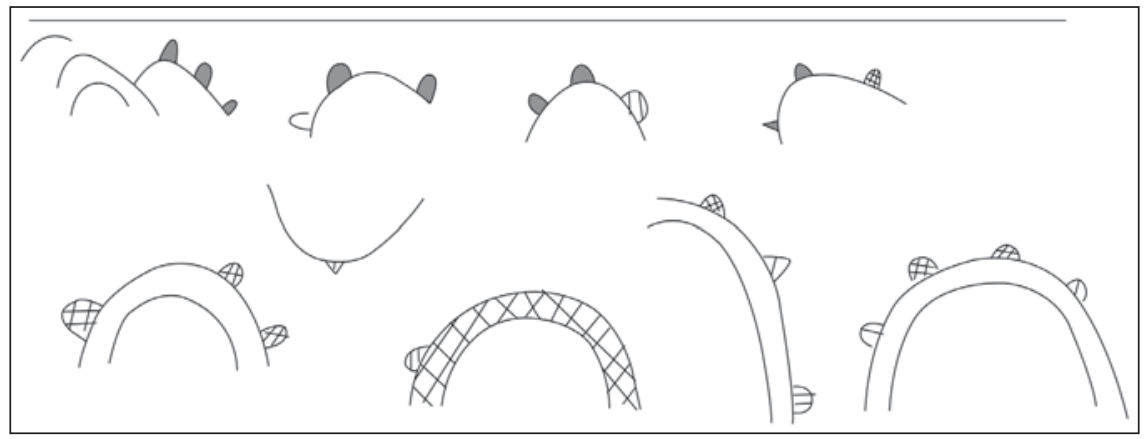

Figure 4. Unidentified engraved jar from the Claude Burkett site (41WD31). 


\section{SUMMARY AND CONCLUSIONS}

The three Caddo ceramic vessels from the W. O. Ziegler (41WD30) and Claude Burkett (41WD31) sites in the upper Sabine River basin are grog-tempered, and each was fired in a reducing environment and cooled in the open air. The vessels from the Claude Burkett site are from a Middle Caddo period (ca. A.D. 12001400) component based on the identification of a Sanders Engraved carinated bowl. The bottle from the W. O. Ziegler Farm site is a Late Caddo period, Titus phase (ca. A.D. 1430-1680), Ripley Engraved type with a scroll and circle motif that features equal-arm cross decorative elements.

\section{ACKNOWLEDGMENTS}

Thanks to the staff at the Texas Archeological Research Laboratory for access to these Wood County, Texas collections for ceramic vessel documentation purposes. Lance Trask prepared the figures in this article.

\section{REFERENCES CITED}

Wilson, A. M. and A. T. Jackson

1930 Field Notes: Work Done at Indian Sites, Wood County, Texas. MS on file, Texas Archeological Research Laboratory, The University of Texas at Austin. 